\title{
Old Mice Epididymal Sperm Quality After Short Term Gavage of Cogon Grass Root Ethanol Extract
}

\author{
Alkaustariyah Lubis, ${ }^{1}$ Rini Widyastuti, ${ }^{2,3}$ Sondi Robianto, ${ }^{1}$ Madeleine Priscilla, ${ }^{1}$ \\ Mas Rizky A. A. Syamsunarno ${ }^{4,5}$ \\ ${ }^{1}$ Medical Study Program, Faculty of Medicine, Universitas Padjadjaran Bandung, Indonesia, ${ }^{2}$ Laboratory of \\ Animal Reproduction and Artificial Insemination, Department of Animal Production Animal Husbandry \\ Faculty Universitas Padjadjaran Bandung, Indonesia, ${ }^{3}$ Veterinary Medicine Study Program, Faculty of Medicine \\ Universitas Padjadjaran Bandung, Indonesia, ${ }^{4}$ Departement of Biochemistry and Molecular Biology Faculty of \\ Medicine Universitas Padjadjaran Bandung, Indonesia, ${ }^{5}$ Biotechnology Study Program Postgraduate School, \\ Universitas Padjadjaran Bandung, Indonesia
}

\begin{abstract}
Cogon grass (Imperata cylindrica) has been known as traditional herb because of its antioxidant activity. The oxidant level in the body increases linearly with age. Antioxidant works by decreasing the vulnerability of mammalian spermatozoa towards free radical attack. This study aimed to determine whether the active compound of Imperata cyclindrica root extract improved or damaged sperm function in old mice. This was a complete randomized study performed in the Mouse Animal Laboratory Faculty of Medicine, Universitas Padjadjaran during the period of August to December 2017. This study was carried out by oral administration of three different doses i.e 115, 230, and $345 \mathrm{mg} / \mathrm{kg}$ body weight of cogon grass root ethanol extract into 24- weeks-old DDY strain mice for 14 days. Results showed no significant difference in body weight and testicular index before and after treatment $(\mathrm{p}<0.05)$. Interestingly, sperm concentration decreased significantly in $345 \mathrm{mg} / \mathrm{kgBW}$ group when compared to control $(2.03 \times 106$ and 6.43x106 respectively, p<0.05). On the other hand, sperm motility and sperm with normal morphology increased following dose pattern, although not significantly, when compared to control $(p<0.05)$. Hence, cogon grass root ethanol extract cannot maintain optimum epididymal sperm quality in old mice.
\end{abstract}

Key words: Aging, Imperata cylindrica, sperm quality

\section{Kualitas Sperma Epididimis Mencit Tua setelah Pemberian Ekstrak Akar Alang-Alang secara Oral Jangka Pendek}

\begin{abstract}
Abstrak
Alang-alang (Imperata cylindrica) dikenal sebagai obat tradisional karena efek antioksidan yang dimiliki. Kadar oksidan pada tubuh meningkat seiring pertambahan usia. Antioksidan bekerja dengan cara mengurangi kerentanan spermatozoa terhadap radikal bebas. Penelitian ini bertujuan untuk menentukan apakah komponen aktif ekstrak akar alang-alang dapat memperbaiki atau merusak fungsi sperma pada mencit tua. Penelitian ini dilakukan di Laboratorium Hewan Fakultas Kedokteran Universitas Padjadjaran periode Agustus hingga Desember 2017. Eksperimen dibagi menjadi satu grup kontrol dan tiga grup perlakuan dengan dosis 115, 230 dan $345 \mathrm{mg} / \mathrm{kgBB}$ selama 14 hari. Hasil menunjukkan tidak ada perbedaan signifikan pada berat badan dan index testis sebelum dan sesudah perlakuan. Menariknya, jumlah sperma menurun dengan signifikan pada kosentrasi

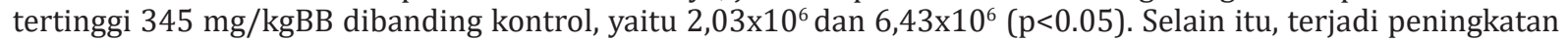
motilitas sperma dan morfologi normal secara gradual hingga dosis tertinggi dibanding dengan kontrol walaupun tidak signifikan. Berdasar atas hasil yang didapat, ekstrak akar alang-alang dapat menjaga kualitas sperma pada mencit tua walaupun tidak optimal.
\end{abstract}

Kata kunci: Imperata cylindrica, kualitas sperma, penuaan

Correspondence: Rini Widyastuti, drh, M.Si, Laboratory of Animal Reproduction and Artificial Insemination, Department of Animal Production Animal Husbandry Faculty Universitas Padjadjaran, Jalan Bandung-Sumedang KM.21 Jatinangor, West Java, Email: r.widyastuti@unpad.ac.id, widyastuti25@gmail.com 


\section{Introduction}

Aging is a natural process comprising of irreversible changes due to a myriad of endogenous and environmental factors at the level of all organs and systems. Aging is characterized by accumulation of cellular damage and associated with increase of reactive oxygen species (ROS). The presence of high concentration of ROS inducesoxidative stress that has a detrimental effect on sperm quality. Naturally, an individualwill produce antioxidants to dispose,scavenge, and suppress the formation of ROS and lipid peroxidation. For example: seminal fluid and semen contain enzymatic and non enzymatic natural antioxidant including vitamin C, vitamin E, superoxide dismutase, glutathione and thioredoxin that neutralize free radical activity and protect sperm from ROS. ${ }^{1}$ With aging, the ability to produce natural antioxidant capacity is diminishing. Therefore, it is importantto identify strategies to prevent the negative effect of ROS by administration an exogenous antioxidant.

Synthetic and natural antioxidant are added as food additive to prevent food deterioration. In recent years, much attention has been devoted to natural antioxidants and their association with health benefits. ${ }^{2}$ Alternative therapies such as herbal plants have more benefts since they are less invasive compared with other methods. Imperata cylindrica is a pernicious perennial grassy weed of significant importance in tropical and subtropical zones. Cogon grass thrives extensively in Indonesia because it is highly adaptive to harsher environment becoming ground cover. It has been used as traditional herbs for diuresis and hypertension. ${ }^{3}$ It is also easy to find and inexpensive from regular drugs.

Phytochemical studies on theroots of $I$. cylindrica resulted in the isolation of mostly phenolic compounds such as flavonoids, simple phenols, phenolicacids, coumarins, and lignans, terpenoid, tanin, alkaloid ${ }^{4}$ which exhibited diverse pharmacological uses, such as cytotoxic, neuroprotective, and vasodilativeactivity. Polyphenol compound also has antioxidant activity and proven to reduce hypertension, decrease triglyceride absorbtion in small intestine, and lower blood glucose in mice. ${ }^{3}$ However, there was no previous data about the effect of Cogon grass on fertility of old mice but it is likely to maintain sperm function based on the phytochemical compounds contained. The aim of this study was to investigate the effect of administration of ethanol extract of Cogon grass on testicular index and epididymal sperm quality in old mice.

\section{Methods}

This study used complete randomized design and was performed in the Mouse Animal Laboratory Faculty of Medicine, Universitas Padjadjaran on August to December 2017. Cogongrass was purchased from Solo, Central Java, Indonesia then macerated with ethanol $95 \%$ for 72 hours, filtrated with a vacuum filter, and concentrated in a vacuum evaporator. Ethanol extract of cogon grass root was standarized in Faculty of Pharmacy, Universitas Padjadjaran.

Mice are sexualy mature after 8-week-old and considered as adults. ${ }^{5}$ Twenty four weeks old male DDY mice were purchased from PT Bio Farma, Indonesia. Animals were housed in plastic cages under 24 hours light and was aclimatized for 7 days to prevent stress. Animals with fed with standard food and tap water. The studywas approved by ethics Review Committee Faculty of MedicineUniversitasPadjadjaran (1263/UN6. C10/PN/2017).

Animals were divided into four groups: groups I, II and III were treated orally with alang-alang root extract dissolved in CMC $0.5 \%$ at 115,230 and $315 \mathrm{mg} / \mathrm{kg}$ body weight for 14 days. Group IV was treated orally with CMC $0.5 \%$ alone and served as control.

The mice were anasthetized using isoflurane and sacrificed with cervical dislocation after the last day of treatment. Testis was isolated from the adherent tissue and weighed to calculated testicular index with formula:

\section{Testicular index =testis weight $\times 100$ body weight}

Sperm were collected from epididymis then minced 100 times in $1 \mathrm{~mL}$ of $\mathrm{NaCl}$. Approximately $10 \mu \mathrm{L}$ of the diluted sperm suspension wastransferred to thehemocytometer and was allowed to stand for 5 minutes. The cells that settled on neubauerchamber were counted under microscopy to calculate sperm concentration (magnification 200x) ${ }^{6}$

The percentage of motile sperm was evaluated visually in each sample by viewing a drop of sperm suspension diluted Tris buffer solution. Two hundred of sperm cells were counted to assist the sperm motility. ${ }^{6}$ Sperm morphology was assesed by using smear preparation with Eosin Nigrosin staining. Two hundred sperm 
Table 1 Mice Sperm Count and Motility After 14 Days Administration of Cogon grass Root Ethanol Extract

\begin{tabular}{lll}
\hline \multicolumn{1}{c}{ Groups of Treatment } & \multicolumn{2}{c}{ Sperm Count (/ml) } \\
\cline { 2 - 3 } & Right & Left \\
\hline Group A: Control & $6,43 \times 10^{6^{*}}$ & $7,96 \times 10^{6}$ \\
Group B: $115 \mathrm{mg} / \mathrm{kgBW}$ & $2,05 \times 10^{6}$ & $5,00 \times 10^{6}$ \\
Group C: $230 \mathrm{mg} / \mathrm{kgBW}$ & $3,52 \times 10^{6}$ & $3,48 \times 10^{6}$ \\
Group D: $345 \mathrm{mg} / \mathrm{kgBW}$ & $2,03 \times 10^{6^{*}}$ & $2,95 \times 10^{6}$ \\
\hline
\end{tabular}

* Asterisk in the same column indicates statistically significant different $(\mathrm{p}<0.05)$

cells were counted and classified into normal and abnormal sperm morphology using light microscope at 400x magnification. The abnormal sperm morphology differentiated into head and tail defect. Head defect criteria were classified as acephaly, microcephaly, no hook, and double head. Tail abnormality criteria were no tail, bent, short tail, and double tail. ${ }^{5}$

All of data are presented as mean \pm standard deviation. The degree of significance was set at $\mathrm{p}<0.05$ using one-way ANOVA and Tukey HSD posthoc. All the analyses were carried out using SPSS software version 16 ( SPSS Inc, Chicago, IL, USA).

\section{Results}

The body and testes weightwas measured to know the effect of cogon grass toward the mice growth and testicular index are presented in
Figure 1 and Figure 2. The result showed there is increased in body weight before treatment compared with the last day of treatment. The testicular index decreased in all groups of treatment compared with control. However, the increase of body weight and decrease of testicular index in all group of treatment are not statistically significant compared with control group $(\mathrm{p}<0.05)$.

Table 1 present the epididymal sperm concentration after 14 days administration ethanol extract of Cogon grass root orally. The result showed that there is decrease of sperm concentration in all group of treatment compared with control. The sperm count signicantly reduced about one third in group 345 $\mathrm{mg} / \mathrm{kg}$ body weight dose compared with control $(\mathrm{p}<0.05)$.

The sperm motility is showed in Figure 3. There is gradual increase in followed-dose pattern of all groups compared with control

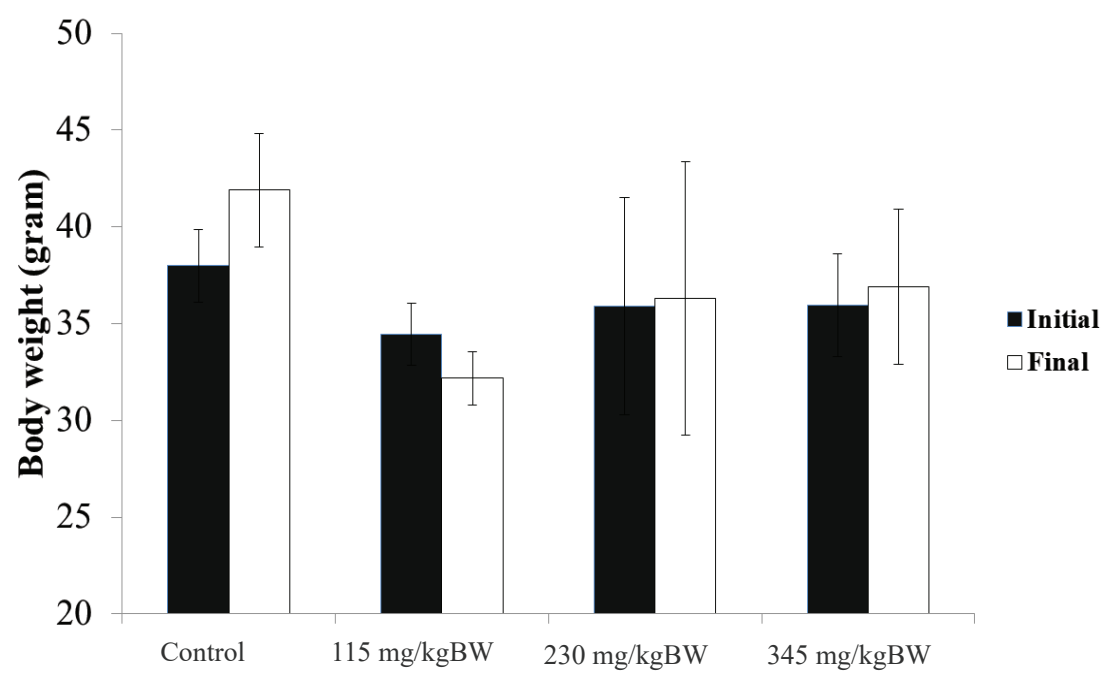

Figure 1 Mice Body Weight Measured on Initial Day and After 14 Days Administration of Cogon grass Root Ethanol Extract 
Alkaustariyah Lubis et al.: The Quality of Epididymal Sperm of Old Mice after Short Term Gavage of Cogon Grass Root Ethanol Extract

Table 2 Head and Tail Normal Morphology After 14 Days Administration of Cogon grass Root Ethanol Extract

\begin{tabular}{lcccccc}
\hline \multirow{2}{*}{ Groups of Treatment } & \multicolumn{3}{c}{ Right (\%) } & \multicolumn{3}{c}{ Left (\%) } \\
\cline { 2 - 7 } & Head & Tail & Total & Head & Tail & Total \\
\hline Group A: Control & $90.5 \pm 3.5$ & $96.9 \pm 1.3$ & $93.7 \pm 5.6$ & $89.5 \pm 2.5$ & $95.4 \pm 3.0$ & $92.5 \pm 1.0$ \\
Group B: $115 \mathrm{mg} / \mathrm{kgBW}$ & $88.5 \pm 1.4$ & $96.9 \pm 1.7$ & $92.7 \pm 3.2$ & $77.2 \pm 3.2$ & $99.7 \pm 0.4$ & $88.5 \pm 2.8$ \\
Group C: $230 \mathrm{mg} / \mathrm{kgBW}$ & $90.9 \pm 4.8$ & $98.5 \pm 2.3$ & $94.7 \pm 3.6$ & $94.5 \pm 2.4$ & $98.4 \pm 1.3$ & $96.5 \pm 2.8$ \\
Group D: $345 \mathrm{mg} / \mathrm{kgBW}$ & $91.3 \pm 3.9$ & $99.4 \pm 0.8$ & $95.4 \pm 3.6$ & $93.6 \pm 2.5$ & $98.5 \pm 1.0$ & $96.1 \pm 1.7$ \\
\hline
\end{tabular}

* asterisk in the same column indicates statistically significant different $(\mathrm{p}<0.05)$

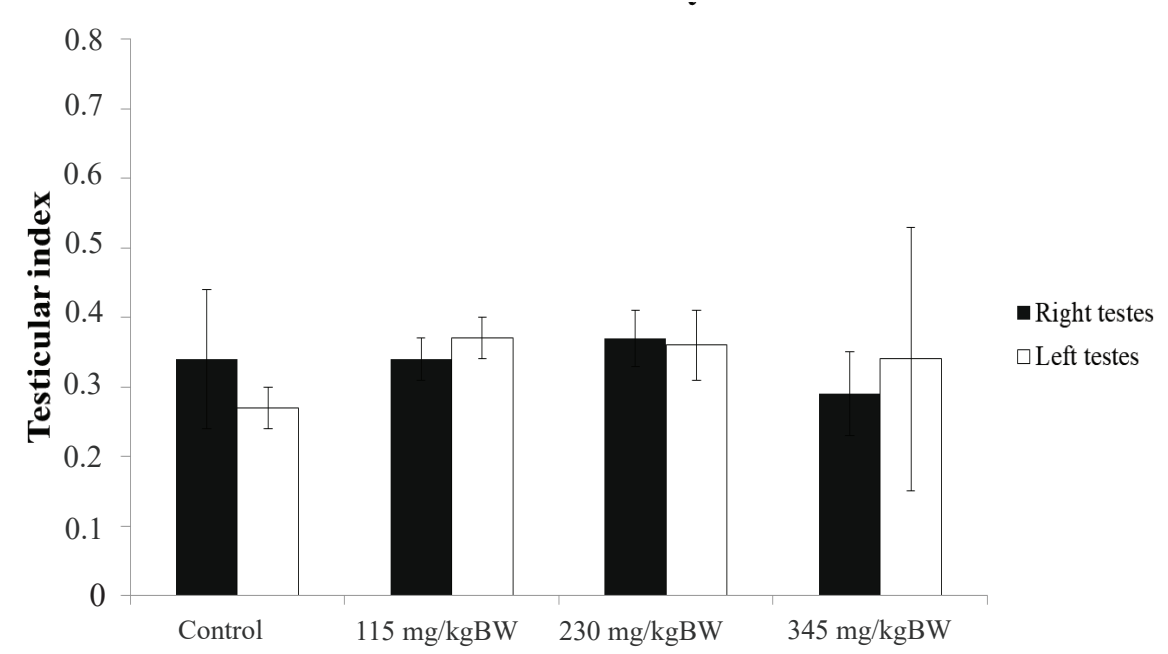

Figure 2 Testicular Index is Testis Weight Divided by Body Weight

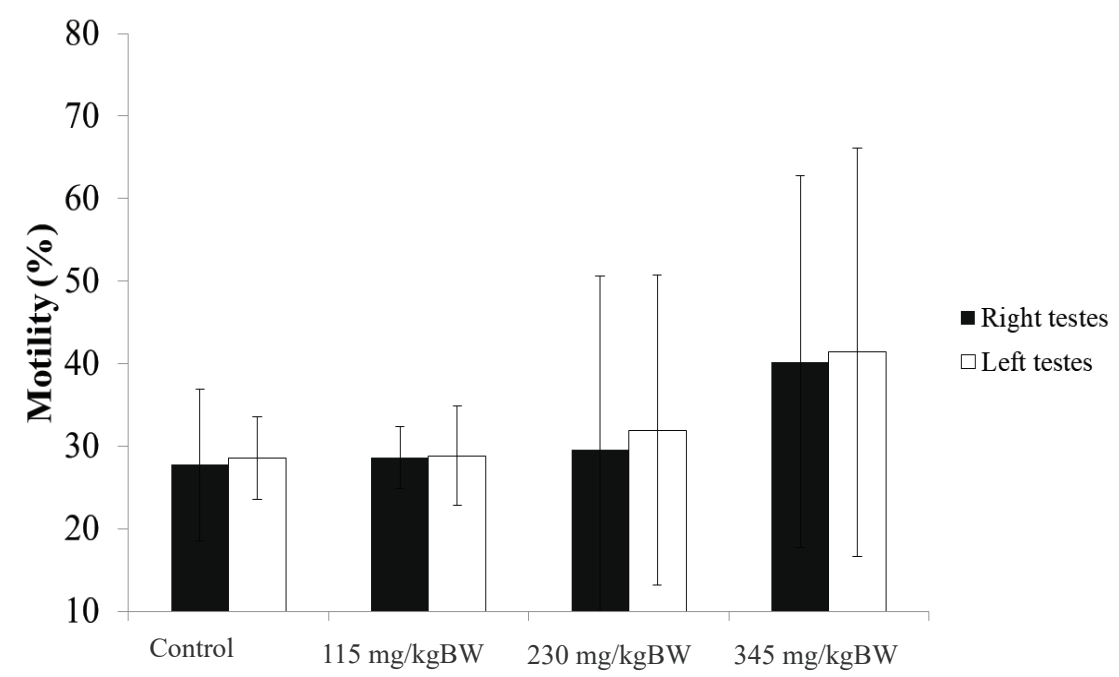

Figure 3 Mice Sperm Motility After 14 Days Administration of Cogon Grass Root Ethanol Extrac 
although no significant different $(\mathrm{p}<0.05)$. The highest increase marked in group $345 \mathrm{mg} / \mathrm{kg}$ body weight.

The percentage of sperm with morphology presented in Table 2. The result showed that there is increase in normal sperm morphology in all group of treatment although not significantly difference compared with control $(p<0.05)$. the increases of normal morphology is dominated by sperm head.

\section{Discussion}

Several studies in previous years have shown association between testicular functions and advancing age. Zitzman ${ }^{7}$ demonstrated on histomorphological studies there is decrease in number of germ cells and Sertoli cells with aging. Previous study showed perm concentration as well as the percentage of sperm with normal morphology declined at the age of 40 . Sperm motility and semen ejaculate volume declined at the age of 43 years and 45 years respectively. ${ }^{8}$

Normal sperm count lower range according to World Health Organization is 15 million per $\mathrm{mL}$ semen. Based on our results, the controlgroup showed that epididymal sperm count is already low $\left(6,43 \times 10^{6}\right) .{ }^{9}$ The agerelated degenerative change that occur in the testis will increase production of dangerous substance such as reactive oxygen species (ROS) and apoptotic signaling mechanism which influences sperm quality, semen volume, sperm count, sperm motility andsperm morphology. The alterations intheir synthesis may cause pathological effects such as decrease of spermatozoa motility and viability, abnormal morphology, lipid peroxidation and stimulate oxidation and increase DNA damage. ${ }^{10}$ It is well understood that ROS induces changes in leydig cells, including decrease in androgen synthesis and changes in the pituitary-testicular axis with subsequent decrease in luteneizing hormone (LH) level. LH itself is responsible for normal leydig cell function and plays an important role in testosterone production which can lead to testicular atrophy and reduce total sperm production. Decreasing hypothalamicpituitary-testes axis and ameliorating circulation function also contributing to reduce effective spermatogenesis. ${ }^{11}$ Previous studies also indicated thatimpairment of LHreceptor function, possibly due to effects of the accumulating load of free oxygen radicals with age, is an important reason for the impaired responsiveness of aged
Leydig cell to LH stimulation and causing decline of steroidogenesis. ${ }^{12,13}$

In the recent study, the there is minimal increase in body weight but reduced testicle size hence decrease in testicular index although not significant. The result is supported by the previous research that administration of Cogon grass extract didn't decrease body weight significantly but reduce reproductive organ size. $^{14}$

Based on the results, the administration ethanol extract of Cogon grass rootpartially maintain sperm quality against degenerative effect and oxidative stressshowed by stability of motility and normal morphology in all group of treatment.The ability to preserve these function is caused by the presence of antioxidant compound in Cogon grass root such as tannin and phenolic compounds. ${ }^{4}$

Naturally, oxidant such as nitric oxide and hydrogen peroxide present in the body and are neutralized by antioxidant like ascorbic acid. A previous study about reducing ability of Methanol extract of Imperata cylindrica (MEIC) show strong effect comparable to standard ascorbic acid. ${ }^{2}$ The phytochemical screening of MEIC revealed the presence of carbohydrate, glycoside, triterpenoids, phenolic compounds/ tannin, flavonoid, proteins, and volatile oils. These compounds reduce oxidative stress by improvement of serum nitric oxide level. ${ }^{15}$ The administration of MEIC exhibit similar effect with administration of a diet rich in onion and modest in garlic to $\mathrm{Cd}$ induced testicular damage and spermiotoxicity ${ }^{16}$ and pomegranate juice consumption in male rats. ${ }^{17}$

The reduce of testicular index may contribute in decreasing sperm concentration in present study. Other factor that contribute to reduced testes size are alkaloid and terpenoid which contained in Cogon grass root that contribute in decreasing sperm concentration by reducing seminiferous tubular diameter and germinal epithelial thickness thus reduce in testosterone synthesis. Decrease in testicular perfusion which caused by atherosclerotic alterations in testicular arterioles may be the primary cause for the degenerating changes in Leydig cells and their reduced capacity to produce androgens. Variation in testicular size suggests that other factors, probably genetic, are also important. ${ }^{18}$

Out result showed the motility of sperm still maintenanced, it may caused by coumarin which contained in Cogon grass root. Coumarin is known to have phospodiesterase (PDE) inhibitory function that may enhance motility of 
sperm by elevating cAMP level. ${ }^{19}$

The increase of normal morphology also caused by the antioxidant activity. Our study showed dominantly head defect compared to tail. The reason why head is the most susceptible component of spermatozoa because it consist of components rich in unsaturated fatty acid which is susceptible to peroxidative damage. ${ }^{8}$ DNA fragmentation determines the shape of the sperm head. Alterations in chromatin condensation are the most frequent nuclear pathology in severe teratozoospermia. Insufficient centrosomal function results in acephalic spermatozoa or tail implantations not aligned with the sperm axis, and dysplastic development of the tail cytoskeleton leads to the short, thick and irregular flagella of dysplasia of the fibrous sheath. ${ }^{20}$

Defective sperm tail are the principal cause of sperm motility disorders. Ultrastructural examination disclosed random flagellar anomalies in the number (lack or duplication), location (dislocations, transpositions) and/ or architectural organization of flagellar microtubules. These findings demonstrate that severe asthenozoospermia is mainly due to structural abnormalities of the tail. ${ }^{20}$

Based on elucidation above, administration of cogon grass root extract with certain dose maintainsperm quality consecutively with aging. The increase in motility and normal morphology can be new promising resource for natural source of antioxidantthat has positive effect to preserve in old mice sperm quality. The further research is needed to know more effect of cogon grass compounds.

\section{Acknowledgement}

This study was supported by Riset Fundamental Unpad (RFU) 2018. We thanks to Asep Sefulloh for providing the mice and Dwi Wahyudha Wira as technical assistance.

\section{References}

1. Tremellen K. Oxidative stress and male infertility-aclinical perspective. Hum Reprod Update. 2008;14:243-58.

2. Padma R, Parvathy NG, Renjith V, Kalpate PR. Quantitave estimation of tannins, phenols and antioxidant activity of methanolic extract of Imperata cylindrica. Int J Res Pharm Sci 2013;4(1):73-7.
3. Zhou X, Wang J, Jiang B, Shang J, Zhao C. A study of extraction process and in vitro antioxidant activity of total phenols from rhizoma imperatae. Afr J Tradit Complement Altern Med. 2013;10(4):175-8.

4. Rong-hua L, Li-na F, Lan-ying C, Gang R, Shisheng $\mathrm{C}$, Zhuo C. Chemical constituents and pharmacological study progress of imperata cylindrical rhizomes. J Jiangxi University Traditional Chinese Med. 2010;22(4):80-3.

5. Yoshida S, Kyoko H, Shigeru O, Hirohisa T, Ken T, Takamichi I. Effects of fetal exposure to carbon nanoparticles on reproductive function in male offspring. Fertil Steril. 2010;93(5):1695-9.

6. WHO, Department of Reproductive Health and Research. WHO laboratory manual for the examination and processing of human semen; 2010.

7. Zitzmann M. Effect of age on male fertility. Best Pract Res Clin Endocrinol Metab. 2013;27(4):617-28.

8. Stone BA, Alex A, Werlin LB, Marrs RP. Age thresholds for changes in semen parameters in men. Fertil Steril. 2013;100:952-8.

9. Cooper TG, Noonan E, von Eckardstein S, Auger J, Baker HW, Behre HM, et al. World Health Organization reference values for human semen characteristics. Hum Reprod Update. 2010;16(3):231-45.

10. Shiva M, Gautam AK, Verma Y, Shivgotra V, Doshi H, Kumar S. Association between sperm quality, oxidative stress, and seminal antioxidant activity. Clin Biochem. 2011;44(4):319-24.

11. Kao SH, Chao HT, Chen HW, Hwang TI, Liao $\mathrm{TL}$, Wei YH. Increase of oxidative stress in human sperm with lower motility. Fertil Steril. 2008;89:1183-90.

12. Wang Y, Chen F, Ye L, Zirkin B, Chen $\mathrm{H}$. Steroidogenesis in Leydig cells: effect of aging and environtmental factors. Reproduction. 2017;154(4):R111-22.

13. Krisnamurthy H, Sairam MR. Mammalian endocrinology and male reproduction biology. Florida: CRC Press; 2015.

14. Widyastuti R, Wira DW, Gita T, Fauziah $\mathrm{N}$, Syamsunarno MR. Efek pemberian ekstrak etanol akar alang-alang (imperata cylindrica) terhadap perubahan berat badan dan organ reproduksi mencit jantan. Jurnal Ilmu Ternak. 2017;17(1):47-51.

15. Zada A, Dewanto JB, Dahlan A, Dhianawaty, D, Syamsunarno MRAA, Mukarromah GR, et al. Root extract of Imperatacylindrica L. improves serum nitric oxide levels in 
diabetic mice. Unity in Diversity and the Standardisation of Clinical Pharmacy Services: Proceedings of the 17th Asian Conference on Clinical Pharmacy (ACCP 2017), July 28-30, 2017, Yogyakarta, Indonesia: CRC Press; 2017.

16. Ola-Mudathir KF, Suru SM, Fafunso MA, Obioha UE, Faremi TY. Protective roles of onion and garlic extracts on cadmiuminduced changes in sperm characteristics and testicular oxidative damage in rats. Food Chem Toxicol. 2008;46(12):3604-11.

17. Türk G, Sönmez M, Aydin M, Yüce A, Gür $S$, Yüksel $M$, et al. Effects of pomegranate juice consumption on sperm quality, spermatogenic cell density, antioxidant activity and testosterone level in male rats.
Clin Nutr. 2008;27(2):289-96.

18. Chemes HE, Alvarez Sedo C. Tales of the tail and sperm head acheschanging concepts on the prognostic significance of sperm pathologies affecting the head, neck, and tail. Asian J Androl. 2012;14(1):14-23.

19. Kumbar MN, Kamble RR, Kamble AA, Salian SR, Kumari S, Nair R, et al. Design and microwave assisted synthesis of coumarin derivatives as PDE inhibitors. Int J Med Chem. 2016;9890630

20. Kuo PL, Chiang HS, Wang YY, Kuo YC, Chen MF, Yu IS, et al. SEPT12-Mictotubules complexesare required for sperm head and tail formation. Int J Mol Sci. 2013;14:221021. 